\title{
The Influence of Motivation, Satisfaction, and Leadership Style of the Teacher Performance
}

\author{
Ezequiel Santos Marques, Alvaro Menezes Amaral, Carla Alexandra da Costa \\ Graduate School, Dili Institute of Technology (DIT), Dili Timor-Leste. \\ Email:esquiel83@gmail.com,alvaromenezesamaral@gmail.com,calexandra56@yahoo.com
}

\section{ABSTRACT}

The objective of this research is to analysis of job motivation which gives influences to the teachers' performance of Catholic Secondary School of Municipio Dili, Timor-Leste to test and analyze the job satisfaction give the influence to the teachers' performance. The hypothesis of this research tested using an analysis instrument, Smart-PLS 3.0. The result showed that the job motivation has a positive influence and significant to the teachers' performance with T-statistic values is 5.993 and also, P-values are 0,000 . Relationship between job satisfaction and the teacher's performance t-statistics values (0.153) and p-values (0.879), the test result showed that job satisfaction didn't give a positive influence and not significant to the teachers' performance. Relationship between leadership style and teachers' performance, T-statistics values (3.098), and P-values (0.002) showed that the leadership style of the school director gave a positive influence but not significant to the teachers' performance. This study can contribute to the government to develop the education policy which quality in Timor Leste, and plan the program of Education Ministry at the curriculum sector and the regulations. Therefore it can help the school director to understand better their function as the school director, as well as help the teachers to understand their job as educators.

Keywords: Work motivation, work satisfaction, leadership style, and teachers achievement

\section{Introduction}

A human resource becomes a determinant factor or asset to decide on the activity which gives the result for an institution or organization. Human resource is important because it has power, ability, and knowledge to educate the people and give success effectively to those who need. Motivation means a worker member or a person with other members in a group to do the work with other departments. According to Afni Can, Yasri (2016), the relationship between the workers becomes a challenge to the motivation between a worker with others. Kiruja EK, E. Mukuru (2013), said that the motivation from the group is important for the members of the group who influence the work and take part in the work being done by them. The group which has high motivation has a great commitment to protecting the credibility of the group.

Satisfaction from a worker when they get the attention of their leader to strengthen their commitment to the workplace. Someone who has satisfaction with the work where he/she does, it will motivate him/her in daily work to raise the performance. A worker who works with all his/her will and out of pressure, he/she will give a good result and establish a strong commitment between the worker and the institution.

Leadership is like a process that influences the other people to comply with what the leader wants, the ability influences the people or organization to achieve the group's objective. According to Slim, W. J. (2005), a leader is a person who has the ability in working together with other people to make something new to the world complicated with technology development. Leadership is an art to lead other people, and attract the attention of people and influence the people who work together to have a good mentality and positive behavior. There are two types of leadership, namely: informal leadership and formal leadership. Informal leadership can be got from the natural formation when it has no pressure or forcefulness to the rule. Formal leadership is acquired from an election from the organization and take the position as leader.

Teachers' performance are like a work result to achieve the development of a teacher who runs his/her work and responsibility (Adeyemi, 2010). A good performance of the teachers is seen from the participation of teachers in the school, in the learning process actively, in teaching by using the good method, in teaching happily, in evaluating the students based on the good method. A good performance of teachers always influences strongly to the outcome of the students in the competition. Teachers' performance will be better, it needs the motivation, satisfaction from a competent leader to give the good motivation to all teachers as well as response to their daily necessity, when the teachers have a good motivation, they will be satisfied with their work they do every day (Akinyi, 2013).

The objectives of this research are 1. Identifying and explaining the work satisfaction regarding the teacher's performance. 2. Identifying and explaining the leadership style regarding the teachers' performance.

\section{Literature Review}

\subsection{Definition of Motivation}


Motivation is that a change of energy in ourselves (personal) to each people who give the signal to make the stimulation and reaction to achieve the objective. Work motivation has a significant relation with teachers' performance (Baihaqi, 2015). Regarding this definition, can be said that motivation influences the activity of the teachers. (Lam and Lambermont, 2010) divided the motivation into two types, namely extrinsic motivation and intrinsic motivation. Intrinsic motivation means give motivation to the necessity which influences satisfaction: all activities which represent the individual to make a dependency on the individual. (Muhsin and Sutomo 2016) also said motivation is the attitude and value which influence the individual to achieve their activity. Invisible attitudes and values which give energy and become a motivator to the individual to achieve the objective.

Afni and Yasri (2016) as they followed Koeswara who declared that the teachers must learn a lot because their work is to motivate the power of mentality. The power of mentality is to make attention or interest, will, aspiration, for each of us, sometimes the teachers have an actively will, oriented attitude, as well as deeds personally in the learning process.

\subsection{Job Satisfaction.}

Satisfaction means a worker feels satisfied when there is something that motivates him/her to the activities that will be done. Job satisfaction becomes a big problem that can give attention to the productivity of a worker and unsatisfied when it relates to the obligation in hard work. Working in an incompatible situation or satisfied in the workplace (Susanto, 2008). Job satisfaction is like an attitude or values from everyone in working in relating to the circumstance of work, the content of work, the relation of work with the other workers at the workplace. Job satisfaction can make people have a responsibility for the work that they do because they feel happy with the work (Edhi and Wahyuddin. (2010)

\subsection{Leadership Style}

Leadership can influence other people to run their work based on the regulation. According to the (Meister and Willyerd, 2010), the job of leadership of the school director, that is relating to motivation and teachers' performance, he emphasized that the leadership has extensive definition where the individual has the initiative to lead with social behavior to regulate, lead, organize, and control other people through the performance, competition, and position.

\subsection{Performance}

Performance of teachers evaluation is an activity to collect the information and a job, according to the information used to get a clear alternative to make a decision (Niswaty, 2018). The first function of evaluation in this factor is to prepare good information for the people to get a policy that can be taken through an evaluation that has been done. The concept of performance means a quickness of work (performance). Performance is a waste to create or the function of the indicators in a job or profession at the same time (Akinyi, 2013).

\subsection{Research Concept}

The imaginative concept is a conceptual model of how the theory has a relation with the factors which make the definition to the important activities: work motivation according to Afifah, T., \& Al Musadieq (2017), X1.1. Always do the work responsibly, X1.2. Doing the job according to target X1.3. having a principle to do the work, $\mathrm{X} 1$. 4. Making the comparison to the job outcome, X1.5. feeling happy in the workplace, X1.6. self-effort to help their friends in the workplace, X1.7. giving important attention to work performance, X1.8. always work hard for the life necessity through the work target, X1.9. feeling happy when receiving appreciation from the work they do, X1.10. receiving a reward for their work, X1.11. supporting the chief and among teachers at the workplace. Work satisfaction according to Zülfü Demirtas (2010), X2.1. satisfied with the work given to me, X2.2. satisfied with the salary that I receive at the workplace, $\mathrm{X}_{2.3}$ satisfied with the promotion, $\mathrm{X}_{2.4}$. Satisfied with the director who always does the dialogue, $X_{2.5}$. satisfied with the friends who work together at the workplace. The leadership of the school director according to Niswaty, R. (2018) $X_{3.1}$ the leader always shows good performance. A leader always shows a good example, $X_{3.2 .}$ a leader always gives trust, $X_{3.3}$. leader hears what the suggestions from his/her member $X_{3.4}$. The leader takes decision justly, $\mathbf{X}_{3.5}$ a leader always motivates me in daily work, $X_{3.6}$. leader helps me preparing a good lesson plan. Teachers' performance according to Ridwan (2009), Y.1 using an adequate method of teaching, Y.2. always supports the students in a learning activity, $Y_{.3 .}$ coming to work on time, $\mathrm{Y}_{4}$ extending the knowledge through the work experiences, $\mathrm{Y}_{.5}$ proving the workability in the group. 


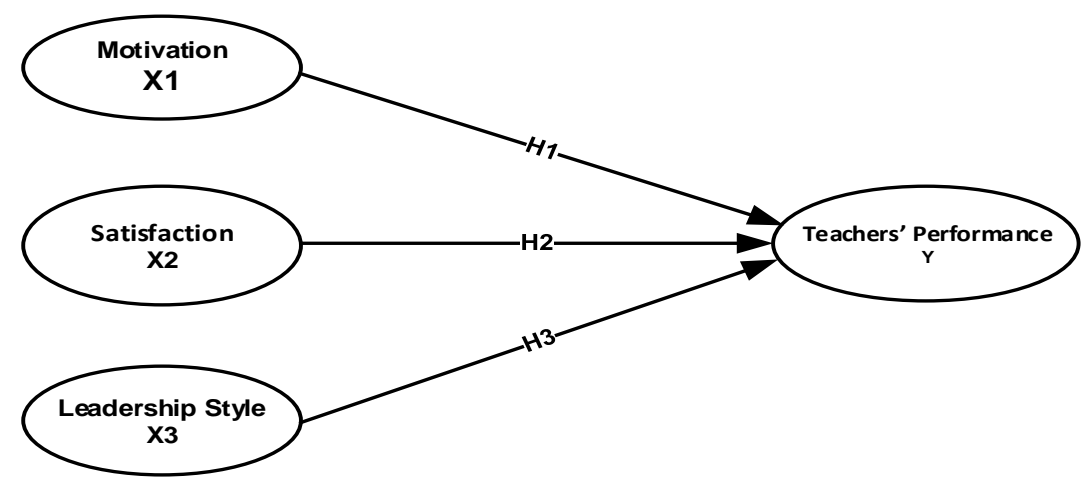

Figure 1. Conceptual Model of Retail e-learning Assessment Effectiveness

\subsection{Hypothesis of Research}

A hypothesis is an assumption, an idea that is proposed for the sake of argument so that it can be tested to see if it might be true. A hypothesis is like a prediction or a temporary response to the problem the researcher does the research. This temporary response in the research to get the result through the collection of data. So that the researchers determine the hypothesis as follows:

$\mathrm{H} 1$ : Work Motivation influence teachers' performance H2: Job Satisfaction influences teachers' performance. H3: Leader style influences teachers' performance.

\section{Method of Research}

A population is a group that attracts the researcher and becomes an object to the research or the whole object to do the research or analyses. According to (Sugiyono, 2014), the population is a general field that has the quality subject, object, and the characteristic through the researcher to conclude all populations, that the result of measurement to the quality. The quality in some characteristics to accumulate about the complete object. The population in this research is the teachers in the Catholic Secondary School, Dili Municipal, a total of 442 .

The samples of the researcher use Slovin Formula to measure it so that the researcher took only 140 people from 442 population. The technique is used to collect data is the questionnaire. This research is to express the psychology aspect that is the attitude or deed of the respondents. Therefore the questions to collect the idea or understanding in accordance with the concrete declaration in this thesis, to form and to make the same analysis to the response about the related declaration or statement can change the number and can change the interpretation (Hopkins, L. 2015).

\section{Result}

\subsection{Reliability Test}

In this research, reliability test use the Cronbach Alpha, composite reliability and average variance extracted (AVE). The result of the reliability test from Cronbach Alpha, composite reliability, and average variance extracted (AVE) showed that the value of all is higher than minimum standard Cronbach Alpha $(0,7)$, composite reliability (higher or the same 0.7 ). The reliability value is less than 0.6 , considered little, not better, but 0.7 can be received, and more than 0.8 is better (Sugyono, 2014). The result test show that all values from Cronbach alpha to the higher variable 0.6, because those are the instruments used to analyses the variable, it is said reliable, and average variance extracted (higher 0.5). 
Vol.2, Issue.2, pp.39-47, 2020

Available online at: https://tljbm.org/jurnal/index.php/tljbm

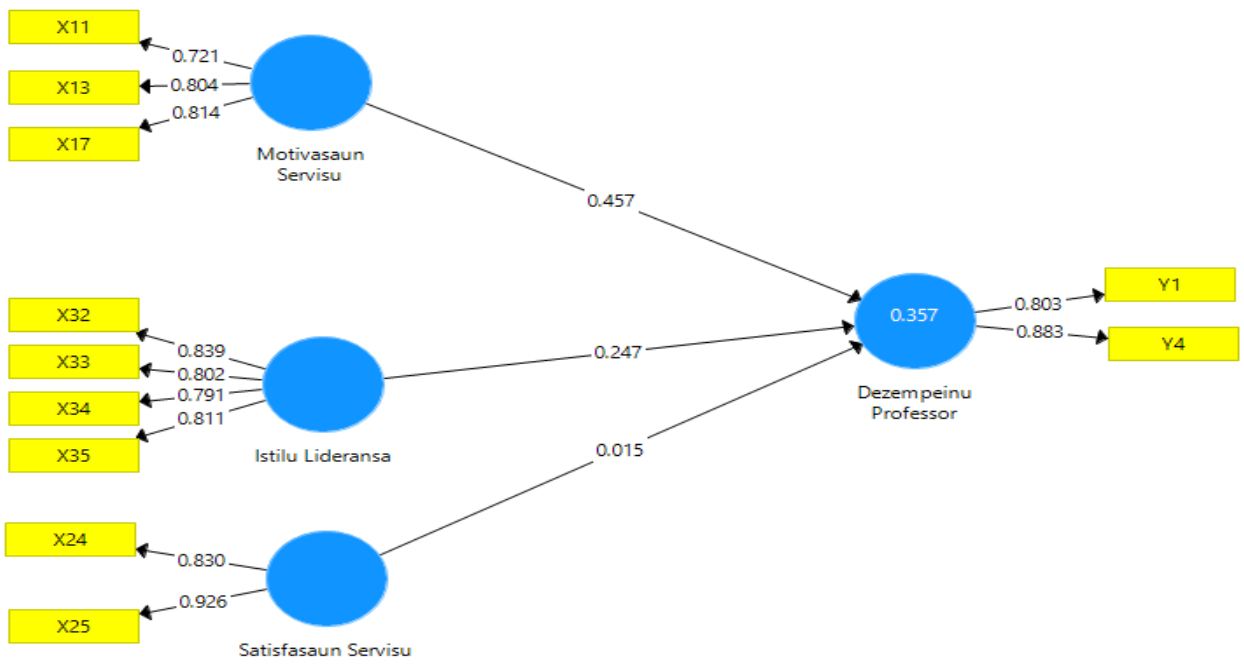

Figure 2. Results of the SMART-PLS Algorithm for Outer Measurement Test

Table 1. Result Reliability Test

\begin{tabular}{|l|c|c|c|}
\hline & $\begin{array}{c}\text { Cronbach's } \\
\text { Alpha }\end{array}$ & $\begin{array}{c}\text { Composite } \\
\text { Reliability }\end{array}$ & $\begin{array}{c}\text { Average Variance } \\
\text { Extracted (AVE) }\end{array}$ \\
\hline Teachers' Performance & 0.601 & 0.832 & 0.712 \\
\hline Work Motivation & 0.688 & 0.824 & 0.610 \\
\hline Leadership Style & 0.827 & 0.885 & 0.658 \\
\hline Work Satisfaction & 0.716 & 0.872 & 0.773 \\
\hline
\end{tabular}

\subsection{Validity Test used Fornell Larscker}

Validity test can be used parameter Discriminant validity and average variant extracted (AVE), in which the indicator can be validate if the value square root of average variant extracted (AVE) from each variable through the correlation value between the latent variable and another variable minimum value is 0.5 (Hair et al. 2014). Based on the test result the discriminant validity, value AVE from each correlation of latent variable higher than other latent variables, and the minimum value 0.690 , minimum value higher than 0.5. Table 2 descibre the test valid used discriminate validity.

Table 2. Validity Test Used Fornell Larscker

\begin{tabular}{|l|c|c|c|c|}
\hline & $\begin{array}{c}\text { Teachers' } \\
\text { Performance }\end{array}$ & $\begin{array}{c}\text { Leadership } \\
\text { Style }\end{array}$ & $\begin{array}{c}\text { Work } \\
\text { Motivation }\end{array}$ & $\begin{array}{c}\text { Work } \\
\text { Satisfaction }\end{array}$ \\
\hline Teachers' Performance & 0.844 & & & \\
\hline Leadership & 0.411 & 0.811 & & \\
\hline Work Motivation & 0.547 & 0.338 & 0.781 & \\
\hline Work Satisfaction & 0.358 & 0.598 & 0.427 & 0.879 \\
\hline
\end{tabular}

\subsection{Validity Test used Cross-loading}

Discriminant validity test can be used the value crossloading from each indicator from a bigger variable compared with cross-loading of other variables, it can be said it is a valid indicator. According to (Hair and Chong, 2017) said that Outer loading from a construct must be bigger through cross-loading from all construct so that the construct can have the discriminant validity. 
Table 3. Cross Loading Validity Test

\begin{tabular}{|c|c|c|c|c|}
\hline & $\begin{array}{c}\text { Teachers' } \\
\text { Performance }\end{array}$ & $\begin{array}{c}\text { Leadership } \\
\text { Style }\end{array}$ & $\begin{array}{c}\text { Work } \\
\text { Motivation }\end{array}$ & $\begin{array}{c}\text { Work } \\
\text { satisfaction }\end{array}$ \\
\hline $\mathrm{X}_{11}$ & 0.313 & 0.093 & 0.721 & 0.270 \\
\hline $\mathrm{X}_{13}$ & 0.424 & 0.245 & 0.804 & 0.309 \\
\hline $\mathrm{X}_{17}$ & 0.508 & 0.390 & 0.814 & 0.399 \\
\hline $\mathrm{X}_{24}$ & 0.247 & 0.491 & 0.380 & 0.830 \\
\hline $\mathrm{X}_{25}$ & 0.365 & 0.558 & 0.378 & 0.926 \\
\hline $\mathrm{X}_{32}$ & 0.365 & 0.839 & 0.225 & 0.449 \\
\hline $\mathrm{X}_{33}$ & 0.328 & 0.802 & 0.330 & 0.528 \\
\hline $\mathrm{X}_{34}$ & 0.309 & 0.791 & 0.340 & 0.472 \\
\hline $\mathrm{X}_{35}$ & 0.328 & 0.811 & 0.213 & 0.497 \\
\hline $\mathrm{Y}_{1}$ & 0.803 & 0.323 & 0.391 & 0.286 \\
\hline $\mathrm{Y}_{4}$ & 0.883 & 0.368 & 0.520 & 0.317 \\
\hline
\end{tabular}

\subsection{Heterotrait-Monotraits Ratio}

Validity test can also be used the parameter HeterotraitMonotrait Ratio (HTMT). Based on this test the value
HTMT of all constructs need less than 0.85 (Henseler $e t$. al., 2016), eventhough there is a factor which recommended to limit the HTMT less than 0.90 (Henseler et al.2015).

Table 4. Heterotrait-Monotraits Ratio (HTMT)

\begin{tabular}{|c|c|c|c|c|}
\hline Teachers' Performance & $\begin{array}{c}\text { Teacher' } \\
\text { Performance }\end{array}$ & $\begin{array}{c}\text { Leadership } \\
\text { Style }\end{array}$ & $\begin{array}{c}\text { Work } \\
\text { Motivation }\end{array}$ & $\begin{array}{c}\text { Work } \\
\text { Satisfaction }\end{array}$ \\
\hline Leadership Style & 0.579 & & & \\
\hline WorkMotivation & 0.811 & 0.415 & & \\
\hline Work satisfaction & 0.528 & 0.774 & 0.598 & \\
\hline
\end{tabular}

Based on the validity test used discriminant validity such as Fornell Larscker Validity Test, Cross-loading Validity Test, and HTMT. The parameter value is bigger than the minimum value, so that the valid construct data can be used in this model.

\subsection{Hypothesis Test}

Hypothesis tests used value $\mathrm{T}$ and value $\mathrm{P}$ in the path coefficient test. Hypothesis test is positive when $T$ values are higher than 1.986, and significant, when $\mathrm{P}$ values are less than 0.05 (Hair et al., 2010; Henseler et al., 2016; Saldanha et al., 2018). In this research, its hypothesis is the work motivation has a positive influence and significant to the teacher's achievement. Analyses result of SMART-PLS 3.0 shows that $\mathrm{T}$ values (3.750) and $\mathrm{P}$ values (0.000). The result show at the Table 5 that work motivation has a positive influence and significant to the teachers' performance so that the hypothesis $\left(\mathrm{H}_{1}\right)$ can be accepted.

In this research, the hypothesis is the work satisfaction has a positive influence and significant to the teacher's achievement. The analysis result SMART-PLS 3.0 shows the $T$ values and $p$ values. The result is shown in the Table 5 that work satisfaction is insignificant and influences to the teachers' performance. In this research, its hypothesis is the leadership style that has a positive influence and significant to the teachers' performance. Analysis result SMART-PLS 3.0 showed $\mathrm{T}$ and $\mathrm{p}$ values are 3.098 and 0.002 . The result showed in Table 5 that the term leadership gives a positive influence but insignificant to the teachers' performance. 
Table 5. Test Result of Path Coefficient

\begin{tabular}{|c|c|c|c|c|c|}
\hline & $\begin{array}{c}\text { Original } \\
\text { Sample }(0)\end{array}$ & $\begin{array}{c}\text { Sample } \\
\text { Mean (M) }\end{array}$ & $\begin{array}{l}\text { Standard Deviation } \\
\text { (STDEV) }\end{array}$ & $\begin{array}{l}\text { T Statistics } \\
\text { (O/STDEV) }\end{array}$ & P Values \\
\hline $\begin{array}{l}\text { Work Motivation -> Teachers' } \\
\text { Performance }\end{array}$ & 0.457 & 0.459 & 0.076 & 5.993 & 0.000 \\
\hline $\begin{array}{l}\text { Work Satisfaction -> } \\
\text { Teachers' Performance }\end{array}$ & 0.015 & 0.012 & 0.100 & 0.153 & 0.879 \\
\hline $\begin{array}{l}\text { Leadership -> Teachers' } \\
\text { Performance }\end{array}$ & 0.247 & 0.256 & 0.080 & 3.098 & 0.002 \\
\hline
\end{tabular}

\subsection{Discussion}

This research has been tested on the influence between work motivation, work satisfaction, leadership style on the teachers' performance at the Catholic Secondary Schools in Municipio Dili, Timor-Leste. Based on the sub-topics to interpret the research result that has been done. Interpretation to the test result of hypothesis which accumulates some aspects such as the relationship between variable which based on the theory, test result outer model and test result in the inner model, the objective is to contribute to the research that is loading factor from each indicator which makes a comparison with the research result that other people have done and give the constructive explanation which related to the practical implication for education in Timor-Leste. Education in Timor-Leste needs to be improved and changed in accordance with the condition of students and teachers (Santos, 2017). The Education Ministry makes the innovation and revision to the old curriculum that many times give the advantage to the students because all the teachers are difficult to make a change to their method of teaching in accordance with the curriculum, (see the Education Ministry, 2014; Santos (2017).

Fundamental Law of education said the educators must organize in a way that promotes academic success and educative to the students. This problem happens because of a lack of formation or training to the educators to extend their pedagogical ability and teaching strategy, and on the other hand lack of facilities to support learning activity, overcrowded students in one classroom, teachers didn't give the opportunity to the students to express their opinion. The other problem is the Portuguese language. The Portuguese language becomes a big challenge in learning activity because the students and teachers can not master the Portuguese language and they can master well neither Portuguese and Tetun.

Therefore, the researcher assumes that all these problems become the fundamental challenge to education in Timor Leste nowadays, even though education in Timor Leste still faces various problems but it is expected that education in Timor Leste has dynamic character will be better in the future. The important thing we keep making a hard effort to improve, renew, and evaluate everything that people face. Several theories presented in this research becomes an instrument to change education in our country.

Based on the result of hypothesis analysis $\left(\mathrm{H}_{1}\right)$ work motivation and teachers' achievement in Catholic Secondary School of Municipio Dili, Timor-Leste, showed that work motivation gives the positive influences and significant to the teachers' performance. (Sugianingrat and Sarmawa, 2017), said that the work a motivation give positive influence and significant to the teachers' performance. The research result of Lam, A., \& Lambermont-Ford (2010), positive and significant relationship between intrinsic motivation factor includes recognizing, working alone, the opportunity for development, acceleration of professionalism, responsibility, sense of belonging to the institution and workers' performance. Based on the description, we conclude that the first work motivation to the works that work aviation gives a positive influence and significant to the teachers' performance. Hypothesis $\left(\mathrm{H}_{2}\right)$ work satisfaction and teachers' performance in the Catholic Secondary School of Municipio Dili, Timor-Leste between the two variables there is no positive relationship. According to (Edhi and Wahyuddin, 2010), work satisfaction didn't influence positively and significantly to the teachers' performance. But work satisfaction is like a positive emotion of everyone to evaluate them and work experience is done. Work satisfaction is like a mirror to observe the sense of other people in the work.

Besides the research conducted by (Susanto, 2008), gave an idea that the work satisfaction doesn't give a significant influence on the teachers' performance. Hypothesis $\left(\mathrm{H}_{3}\right)$ the leadership style of the school director and teachers achievement in Catholic Secondary School of Municipio Dili, Timor-Leste. There are two variables that have a positive relationship.

So that the hypothesis of this research said that the leadership style of the school director to the teacher's performance in the Catholic Secondary School of Municipio Dili, Timor-Leste get the positive reaction to receive the influence which is lower because of the leadership style of the school director to the teachers' performance not significant to the teachers' performance. But also there is a contribution from the variable of leadership style to the teacher's performance that gets from the values that influence the various factors which are not done in this research. 


\section{Conclussion and Implication}

Through the result about the influence of work motivation, work satisfaction, and leadership style of the school director on the teacher performance in the Catholic Secondary School of Municipio Dili, Timor-Leste, conclude that this research accepted from the hypothesis: work motivation gives the positive influence and significant to the teachers' performance in the Catholic Secondary School of Municipio Dili, Timor-Leste. The research showed that a worker who gets good motivation from the leader can extend the performance of the worker is working.

This part can be seen from the intrinsic and extrinsic that related to the teacher competency to help them in working well because of the positive contribution to developing the Catholic Secondary School with their vision in the future. Work satisfaction didn't influence positively and significantly to the teachers' performance in the Catholic Secondary School of Municipio Dili, Timor-Leste. The research result showed that the leadership style of the school director gives a positive influence but not significant to the teachers' performance in the Catholic Secondary School of Municipio Dili, Timor-Leste.

\section{Limitation and Future Research}

This research has numerous limitations such as: (1). The researcher himself has no enough knowledge and references on what the teachers' performance is. (2). As it is the first time for the researcher to research, the research gets difficult to combine the ideas together. (3). The limitations come also from the respondents, that maybe they didn't give the information accurately. (4). Some respondents are a little afraid of giving the information honestly. (5). Some respondents are late to submit the questioner forms. (6). The researcher is sometimes difficult to meet some respondents.

This research also proposes some future research such as: (1). Job motivation needs to be strengthened because it gives a big influence on the teachers' performance in the Catholic Secondary School of Municipio Dili, Timor Leste. (2). Asking to have the next research complete with in-depth interview \& focus group discussion to confirm the response from the respondents. (3). Having the research needs mediation between job motivation, job satisfaction, and leadership style to the teachers' performance. Catholic Secondary School of Municipio Dili can make the promotion quality to the teachers who have good performance. (4). Asking the school directors can extend the quality of teachers through good motivation to extend the teacher's performance. Asking to improve the quality of learning activity to measure the teachers' performance. (5). The result of the teachers' performance needs to extend more and more to motivate the teachers to do their job efficiently. (6). School leaders must give the instruction clearly to the teachers to do their job as a good educator, most teachers are waiting for instruction from their director.

\section{Reference}

Aacha, M. (2010). Motivation and the performance of primary school teachers in Uganda: A case of Kimaanya-Kyabakuza.

Abd Rahim, M. H., Ahmad Zukni, R. Z. J., Ahmad, F., and Lyndon, N. 2012. Green Advertising and Environmentally Responsible Consumer Behavior: The Level of Awareness and Perception of Malaysian Youth. Asian Social Science.

Abraham Sperling (Dalam A.A. Anwar Prabu Mangkunegara, Manajemen Sumber Daya Manusia) Penerbit Rosdakarya, Bandung, 2000.

Adeyemi, T. (2010). Principals "Leadership Styles and Teachers" Job Performance in Senior Secondary Schools in Ondo State.

Adler, N. J. (2004). Leadership, Power, and Influence The Art of Leadership The Art of Leadership.

Afifah, T., \& Al Musadieq, M. (2017). Pengaruh Kepuasan Kerja Terhadap Motivasi Kerja dan Dampaknya Terhadap Kinerja.

Afni Can, Yasri (2016), Pengaruh motivasi kerja, kepuasan kerja dan komitmen organisasi terhadap kinerja karyawan.

Akinyi, O. M. (2013). School-based factors influencing instructional performance of teachers in public primary schools in Aliran Pendidikan Dalam-Perspektif Pendidikan Progresivisme-Dan-Esensialime.Pdf.

Atiya Inayatullah (2011) “Teacher's Job Performance: The Role of Motivation.

Baihaqi, M. I. (2015). Pengaruh Gaya kepemimpinan Kepala sekolah dan Motivasi Kerja Terhadap Kinerja Guru di MA MA'ARIF Selorejo Blitar. Konstruktivisme.

Brown, P. (2005). The Evolving Role of Strategic Management Development.

Can, A., \& Yasri. (2016). Pengaruh Motivasi Kerja, Kepuasan Kerja dan Komitmen Organisasi Terhadap Kinerja Karyawan pada Bank Nagari. Division, Masaka District. Kampala: Makerere University.

Hair, J., Hollingsworth, C. L., Randolph, A. B., Yee, A., Chong, L., Hair, J., .. Chong, L., (2017). An Updated and expanded assessment of PLS-SEM in information systems research.

Hair, J. F., Sarstedt, M., Hopkins, L., \& Kuppelwieser, V. G. (2014). Partial least squares structural equation modeling (PLSSEM). European Business Review, 26(2), 106-121.

Harianto, A. (2016). Pengaruh Motivasi Kerja Terhadap Komitmen Afektif DenganKepuasan Kerja. 
Hasibuan, M.S.P., 2008. Manajemen Sumber Daya Manusia, Cetakan Ketujuh,Jakarta: Penerbit PT. Bumi Aksara.

Henry Pratt Fairchaild, 1960, hal, 174 Dalam Kartini Kartono, Pemimpin dan Kepeminpinan, Jakarta, Raja Grafindo Persada, 2006.

Henseler, J., Ringle, C. M., \& Sarstedt, M. (2016). Testing measurement invariance of composites using partial least squares. International Marketing Review, 33(3), 405-431.

Herman Sarita, B., Zailan, Z., \& Ansir. (2018) Effects of Work Motivation, Leadership Style, and Learning Organization on Teacher Performance Mediated by Organizational Culture. International Journal of Scientific \& Engineering Research.

Hopkins, L. (2015). Partial Least Squares Structural Equation Modeling (PLS-SEM) An Emerging Tool in Business Research. European Business Review.

Humberman; Metode Penelitian Kualitatif; Universitas Indonesia, Jakarta, 1992.

Ikoya, P. O. (2008). Sentralisasi dan Desentralisasi Sekolah' Fisik Fasilitas Manajemen di Nigeria.

Jaja Sudarjat1, Thamrin Abdullah 2, Widodo Sunaryo (2015) Supervision, Leadership, and Working Motivation to Teachers' Performance. Kadibo Division, Kisumu County, Kenya. Nairobi: University of Nairobi. Kepemimpinan Masa Depan. Bandung: PT. Reflika Aditama.

Kiruja EK, Elegwa Mukuru (2013). "Effect of Motivation on Employee Performance In Public Middle-Level Technical Training Institutions In Kenya". Journal of Advances in Management and Economics ISSN:2278-3369 Vol 2-issue 4.

Lam, A., \& Lambermont-Ford, J. P. (2010) Knowledge Sharing in Organizational Contexts: A Motivation-Based Perspective. Journal of Knowledge Management.

Lavy, S., \& Bilbo, D. L. (2009). Fasilitas Pemeliharaan Praktek Manajemen di Sekolah-Sekolah Umum.

Lawrie, G., \& Cobbold, I. (2004). Third-Generation Balanced Scorecard: Evolution.

M. Hitt, R. Duane, E. H. (2000). No Title: Strategic Management.

Ma'ruf, A. (2014). Aliran pendidikan dalam perspektif pendidikan progresivisme dan esensialime program dan esensialisme. http://jurnal.yudharta.

Meister, J. C., \& Willyerd, K. (2010). Leadership in 2020. Leadership Excellence.
Muhsin, N., \& Sutomo, Y. (2016). Pengaruh Kepribadian Dan Motivasi Kerja Terhadap Kinerja Guru Dimoderasi Budaya Organisasi. Pada Madrasah Tsanawiyah Swasta Kecamatan Winong Kabupaten Pati. Nigeria. Current Research Journal of Economic Theory, 3(3): 84-92.

Niswaty, R. (2018). Pengaruh Gaya Kepemimpinan Kepala Sekolah Terhadap Kinerja Guru The Influence of Headmaster Leadership Style on Teacher Performance, of an Effective Strategic Control Tool.

Ridwan. 2009. Metode dan Teknik Menyusun Proposal Penelitian. Bandung : Alfabeta.

Roberts, L. W. (2009). Mengukur Fasilitas Sekolah Kondisi:. Ilustrasi Pentingnya Tujuan.

Saldanha, E. D. S., Rahyuda, I. K., Kerti Yasa, N. N., \& Sukaatmadja, I. P. G. (2018). The Role of Business Strategy in Mediating the Relationship Between Industrial Competition and Performances: A Study in the Higher Education Industry in Timor-Leste. European Journal of Business and Management, 10(8), 152-172.

Santos (2017), Filosofia Edukasaun, Instituto Católico Para a Formação de Professores - Baucau-Diocese de Baucau, TimorLeste.

Sedarmayanti. (2010). Reformasi Adminitrasi Publik, Reformasi dan Birokrasi.

Slim, W. J. (2005). A Guide to Developing Enlightened Leadership.

Sugianingrat, I. A. P. W., \& Sarmawa, I. W. G. (2017) Effect of work Culture on Employee Performance with work Motivation as Mediator: Study at Non-Star Hotel in Denpasar-Bali, Indonesia. International Journal of Economics, Commerce, and Management.

Sugiyono. (2014). Metode Penelitian Kuantitatif Kulitatif dan R\&D. Bandung:Alfabeth.

Suharsimi Arikunto, Prosedur Peskiza. Suatu Pendekatan Praktis, Penerbit Bina Aksara, 2004

Susanto, L. G. (2008). Analisis Pengaruh Motivasi Kerja, Kepuasan Kerja dan Gaji terhadap Kinerja Karyawan. Skripsi, Semarang: Universitas Katolik Soegijapranata.

Uline, C., \& Tschannen-Moran, M. (2008). Dinding Berbicara: Interaksi Kualitas Fasilitas, Iklim Sekolah, dan Prestasi Belajar Siswa.

Winardi SE, Kepemimpinan Dalam Managemen, Rineka Cipta, Jakarta Indonesia, 2000. 
Yuliansyah, Y., Gurd, B., \& Mohamed, N. (2017). The significance of business strategy in improving organizational performance. Humanomics. 